音声言語医学 $47 ： 379-383,2006$

原

\title{
岡山県新生児聴覚スクリーニングの現状と課題
}

\author{
福田章一郎 ${ }^{11}$ 塚村 恵子1) 福島 邦博2)
}

\begin{abstract}
要 約：岡山県では平成 13 年 7 月より岡山県新生児聴覚検查事業を開始した. 現在では全出 生児の約 $75 \%$ がスクリーニング可能となっている. 平成 17 年 3 月時点までに 48 例の両側難聴 児と 34 例の一側性難聴児が発見された。 48 例中, 軽・中等度難聴児は $43.8 \%$ と聴力程度にか かわらず発見が可能であり，ローリスク児も $60.4 \%$ と多かった. しかし，全出生児のうち残さ れた $25 \%$ のスクリーニング未受診児への対応の必要性は認識されてはいるがその対応は容易 ではない. 後天性および進行性難聴の存在により, 長期的な観察の必要性を再認識させられた。 同時に, スクリーニング pass であってもその後, 聴こえあるいはことばの遅れを心配して来園 するケースも少なからず存在するため，スクリーニング後は健診など従来難聴発見に用意され ていたシステムをさらに充実させることが療育的な援助の遅れを少なくするためには重要であ ると考えられる。
\end{abstract}

索引用語：新生児聴覚スクリーニング，難聴のリスク因子，両側難聴，進行性難聴

\section{Newborn Hearing Screening in Okayama Prefecture}

\author{
Shoichiro Fukuda ${ }^{1)}$, Keiko Tsukamura' ${ }^{1)}$ and Kunihiro Fukushima ${ }^{2)}$
}

\begin{abstract}
Newborn hearing screening was introduced in Okayama Prefecture in July 2001 , and approximately $75 \%$ of newborn babies in this district are currently screened every year. As of May 2005, 48 children have been diagnosed as having bilateral hearing impairment and $43.8 \%$ of these cases involved mild to moderate hearing loss ( $30 \mathrm{dBHL}$ to $70 \mathrm{dBHL}$ ). This fact suggests that the hearing screening system can effectively identify infants even with mild to moderate hearing loss. The screening system also effectively identified hearing-impaired children without risk factors for deafness more frequently (60.4\%) than those with risk factors (39.6\%). During this same period, 26 additional cases visited Kanariya Gakuen although they initially received passing results in the newborn hearing screening. Three of these cases were ultimately diagnosed as having a hearing loss, with diagnoses of acquired hearing loss caused by meningitis ( 1 case), bilateral progressive hearing loss ( 1 case), and unilateral progressive hearing loss (1 case). These findings suggest that newborn hearing screening in Okayama Prefecture has been able to successfully detect many hearing-impaired infants from the very inception of this system.
\end{abstract}

岡山かなりや学園 ${ }^{1)}$ : ₹ 700-0927 岡山県岡山市西古松 321-102

岡山大学大学院医歯学総合研究科耳鼻咽喉 - 頭頸部外科学 ${ }^{2)}$ ：干 700-8558 岡山県岡山市鹿田町二丁目 5-1

${ }^{1)}$ Okayama Kanariya Gakuen, Auditory Center for Hearing Impaired Children: 321-102, Nishifurumatsu, Okayama City, Okayama 700-0927

${ }^{2)}$ Department of Otolaryngology-Head \& Neck Surgery, Okayama University Postgraduate School of Medicine, Dentistry and Pharmaceutical Science: $2-5-1$, Shikata-cho, Okayama City, Okayama 700-8558

2006 年 3 月 31 日受稿 2006 年 6 月 7 日受理 
The importance of hospital-based or public health check-ups for children, however, should still be emphasized to identify hearing-impaired children who underwent no hearing screening during their infancy.

Key words: newborn hearing screening, risk factor for deafness, bilateral hearing loss, progressive hearing loss

はじめに

新生児期における聴覚障害児のマススクリーニング は 1960 年にDowns らによって始められて以降いろ いろな手法や機器が試みられてきたが，その効果と効 率性の観点からシステムとして定着するにはいたらな かった ${ }^{1,2)}$. しかし，自動聴性脳幹反応検査（以下自動 ABR）および耳音響放射というスクリーニング機器の 出現により,欧米に続き本邦でも平成 13 年よりモデル 事業を通して新生児聴覚スクリーニングが導入されつ つある ${ }^{3,4}$ 。また， 新生児期に発見された聴覚障害児の 療育効果に関する報告 ${ }^{5}$ も見られるが，十分に議論が 尽くされてはおらず結論にはいまだ慎重さが求められ ている.

岡山県でも平成 13 年 7 月より岡山県新生児聴覚検 查事業を開始した．事業の流れのなかで当園が精密検 査後の療育受け入れ機関になっているため, 療育ある いは経過観察が必要な両側聴覚障害児および一側性難 聴児の発見とその後の状況の把握が可能となってい $3^{6)}$. 今回平成 17 年 3 月時点までに当園に聴覚評価の ために来園したスクリーニング受診児の分析を通し， 岡山県の新生児聴覚スクリーニングシステムの現状と 課題を検討したので報告する。

表 1 スクリーニング事業で来園した児の診断

\begin{tabular}{ccccc}
\hline 年度 & 両側難聴 & 一側性難聴 & 聴力正常 & 計 \\
\hline $\mathrm{H} 13$ 年度 & 5 & 4 & 3 & 12 \\
$\mathrm{H} 14$ 年度 & 13 & 5 & 5 & 23 \\
$\mathrm{H} 15$ 年度 & 18 & 10 & 13 & 41 \\
$\mathrm{H} 16$ 年度 & 12 & 15 & 10 & 37 \\
$\quad$ 計 & 48 & 34 & 31 & 113 \\
\hline
\end{tabular}

\section{対象と方法}

平成 13 年 7 月より平成 17 年 3 月までに自動 $\mathrm{ABR}$ （Natus Algo）による岡山県新生児聴覚検査事業を受 け，その後療育および聴覚評価を目的に当園に来園し た 139 例を対象とした。1 139 例中スクリーニング事業 のなかで両耳あるいは片耳の難聴が疑われたため来園 したのは 113 例であった.残りの 26 例はスクリーニン グで両耳 pass あるいは片耳 refer にて経過観察の対 象外となった後, 聴こえの疑いあるいはことばの遅れ を主訴に来園した児である。これら 139 例のスクリー ニング時およびスクリーニング終了後の経過を追っ た.

\section{結＼cjkstart果}

来園したスクリーニング受診児 139 例のうち，スク リーニング事業で両側あるいは一側の難聴が疑われ， 療育および聴覚評価を主訴に来園した 113 例の診断 は, 両側難聴 48 例, 一側性難聴 34 例, 聴力正常 31 例 であった (表 1). 両側難聴であった 48 例中 40 例 (83.3 \%）は生後 3 力月までに難聴が発見されていた。しか し, 重複障害児 2 例, 口蓋裂児 1 例, 軽度難聴児 1 例 の 4 例は 8 力月に診断を受けており，診断までに時間 を要していた（表2).

また， 6 カ月までにカウンセリング，補聴等の療育 が開始されていたのは 43 例で $89.6 \%$ であった。残り の 5 例は診断が 6 力月以降であった 4 例と超低出生体 重児 1 例で，9 カ月までには療育が可能となっていた (表 2).また, 療育までの期間は, 全例 3 力月以内であ った.

両側難聴 48 例の聴力程度は, 軽度難聴 8 例, 中等度 難聴 13 例, 高度難聴 27 例で, 軽・中等度難聴を併せ ると $43.8 \%$ であった。 48 例中ハイリスク児は 19 例

表 2 新生児聴覚検査事業で発見された症例の難聴発見および療育開始年齢

\begin{tabular}{|c|c|c|c|c|c|c|c|c|c|c|}
\hline 月歯令（生後） & 1 力月 & 2 力月 & 3 力月 & 4 力月 & 5 力月 & 6 力月 & 7 力月 & 8 力月 & 9 力月 & 計 \\
\hline 難聴発見 & 21 & 9 & 10 & 1 & 1 & 2 & 0 & 4 & 0 & 48 \\
\hline 療育開始 & 15 & 11 & 11 & 3 & 1 & 2 & 1 & 1 & 3 & 48 \\
\hline
\end{tabular}


$39.6 \%$ ，ローリスク児は 29 例 $60.4 \%$ でハイリスク児 の割合は有意に低かった（表 3)。ハイリスク児はそれ ぞれ軽度難聴 1 例 (12.5\%), 中等度難聴 3 例 (23.1\%), 高度難聴 15 例 $(55.6 \%)$ で, 聴力程度が厳しいほどリ スク因子をもつ割合が高くなり高度難聴児では八イリ スク児が $50 \%$ を超えていた。

リスク要因としては，家族性難聴 8 例，母体性風疹 症候群 4 例が多く, 両要因のうち家族性の中等度難聴 1 例を除き他の 10 例は高度難聴であった。他のリスク 因子は頭頸部奇形, 低出生体重, 症候群性難聴などで あった(表 4).

次に，スクリーニング時点では両側 pass で放置と なりその後来園した 26 例の診断は, 髄膜炎後の難聴 1 例, 進行性難聴 1 例の両側難聴 2 例, 進行性が疑われ た 1 例を含む一側性難聴 2 例，聴力正常 22 例であっ た. 来園時の主訴と年齢の関係では, 1 歳以内では聴こ えの確認が多く, 言語表出の時期を迎えた 1 歳過ぎで はことばの遅れを心配して来園するケースが増加する 傾向が見られた（表 5)。

表 3 聴力程度とリスク因子

\begin{tabular}{lrrr}
\hline 聴力程度 & ハイリスク児 & ローリスク児 & 計 \\
\hline 高度 & $15(55.6)$ & $12(44.4)$ & 27 \\
中等度 & $3(23.1)$ & $10(76.9)$ & 13 \\
軽度 & $1(12.5)$ & $7(87.5)$ & 8 \\
計 & $19(39.6)$ & $29(60.4)$ & 48 \\
\hline & & $($ ) & 内は\%
\end{tabular}

スクリーニング pass でありながら難聴と診断され た症例は 3 例であった (表 6)。化膿性髄膜炎の後遺症 による両側難聴と診断された症例 1 は， 1 歳 3 力月時 点で髄膜炎を罹患し小児科入院となり，耳鼻科による $\mathrm{ABR}$ で難聴と診断後, 1 歳 8 力月時点で当園紹介とな り, 療育を開始し, その後人工内耳埋め込み術を受け た.

進行性難聴が疑われる症例 2 は， 1 歳 5 力月違いの 妹の名前を覚え, 10 語程度あった有意語が徐々に消失 し 3 歳時点で呼び掛けに反応しないことを主訴に耳鼻 科受診となり，難聴診断後当園紹介となった。

また，一側性難聴が疑われた症例 3 は, 両側 pass で あったが CD が聴こえないと児が訴えたことを主訴に 来園し，一側性難聴と診断された。

\begin{tabular}{cc} 
表 4 ハイリスク児のリスク因子 \\
\hline リスク因子 & 症例数 \\
\hline 家族性難聴 & 8 \\
風疹症候群 & 4 \\
頭頸部奇形 & 2 \\
低出生体重児 & 2 \\
症候群性難聴 & 2 \\
新生児重度仮死 & 1 \\
胎児感染・薬剤使用 & 1 \\
計 & 20 \\
\hline
\end{tabular}

因子が重複する症例はそのまま加算した。

表 5 スクリーニング pass 巟の主訴

\begin{tabular}{|c|c|c|c|c|c|c|}
\hline \multirow[t]{3}{*}{ 年齢 } & \multicolumn{5}{|c|}{ 主訴 } & \multirow[t]{3}{*}{ 計 } \\
\hline & \multirow[t]{2}{*}{ ことばの遅れ } & \multicolumn{3}{|c|}{ 聴こえの確認 } & \multirow[t]{2}{*}{ 難聴 } & \\
\hline & & 確認 & 家族性 & 中耳炎 & & \\
\hline$\sim 5$ 力月 & & 4 & 2 & & & 6 \\
\hline ～1歳 & & $1(1)$ & & & & 1 \\
\hline$\sim 1$ 歳 5 力月 & 1 & 1 & & & & 2 \\
\hline$\sim 2$ 歳 & 7 & 2 & & & 1 & 10 \\
\hline$\sim 2$ 歳 5 力月 & 3 & & & 1 & & 4 \\
\hline$\sim 3$ 歳 & 1 & & & & & 1 \\
\hline$\sim 3$ 歳 5 力月 & & $1(1)$ & & & 1 & 2 \\
\hline 計 & 12 & 9 & 2 & 1 & 2 & 26 \\
\hline
\end{tabular}

表 6 スクリーニング pass 後の難聴

\begin{tabular}{ccccc}
\hline & 初診時年齢 & Natus Algo & 主訴 & ABR \\
\hline 1 & 1 歳 8 カ月 & 両側 pass & 化膿性髄膜炎による難聴 & 両側無反応 \\
2 & 3 歳 2 カ月 & 両側 pass & 進行性難聴の疑い & 両側無反応 \\
3 & 3 歳 4 カ月 & 両側 pass & $\mathrm{CD}$ が聴こえないと訴え & $\mathrm{R}$ 正常, L 無反応 \\
& & & 父方の祖母難聴 & \\
\hline
\end{tabular}


表 7 スクリーニングの年度別捕捉率

\begin{tabular}{lrcccc}
\hline & 13 年度 & 14 年度 & 15 年度 & 16 年度 & 計 \\
\hline 出生数 & 14141 & 18509 & 17770 & 17655 & 68075 \\
スクリーニング数 & 8361 & 12665 & 13222 & 13098 & 47346 \\
捕捉率 (\%) & 59.13 & 68.43 & 74.41 & 74.19 & 69.55 \\
\hline
\end{tabular}

\section{考察}

岡山県の各年度人口動態統計の出生数を基にした年 度別スクリーニング児数とその捕捉率を表 7 に示す。 初年度は $59 \%$ と低かったが, 検査事業への参加医療機 関の増加に伴い順調に増加し, 16 年度には約 $74 \%$ の捕 捉率となっている.

総スクリーニング受診児 47346 例中，スクリーニン グ後の精密検查で両側難聴と診断された症例は 48 例 であり, 年度別の出現率にばらつきはあるが新生児の 時点での出現率の平均は $0.1 \%$ であった.これは, 従来 考えられていた出現率を支持するものであった. Fortnum の報告では, $40 \mathrm{~dB}$ 以上の永久的な難聴児の出現 率は $0.078 \sim 0.18$ ，また先天性のみに限ると $0.071 〜$ 0.152 ,さらに感音難聴だけにすると $0.054 \sim 0.145$ と 条件を変えることで数字のバラツキが見られた ${ }^{7)}$. 今 回の $0.1 \%$ というわれわれの結果は平均的な数値と考 えられるが, 残された約 $25 \%$ のスクリーニング末受診 児を経過観察することで, 今後出現率の継続的な調査 が必要である。

今回 48 例中軽度難聴 8 例, 中等度難聴 13 例が発見 された. 従来, 高度難聴の発見は早期に可能であるが, 聴力が軽い場合その発見は遅れる傾向が指摘されてい $た^{8)}$. 今回スクリーニング実施により軽・中等度難聴の 発見が容易になり, スクリーニングの効果の一つに挙 げられる。しかし, 補聴あるいは療育開始時期のカウ ンセリングに困難さも残るため療育を効果的に行うた めには慎重な配慮が求められる.

一側性難聴と診断された症例は 34 例でその出現率

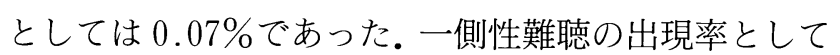
Berg は聴力レベルの違いにより $0.3 \sim 1.3 \%$ と高い出 現率を報告しているが2), 難聴側の程度や原因が不明 確であり本報告との比較は容易ではない。また, 岡山 県では両側性の難聴と異なりスクリーニング後の精密 検查機関で経過観察されているケースもあるため実態 を把握しきれているとはいいがたい。しかしながら， スクリーニング pass 児で進行性が疑われる一側性難 聴も1例発見され，また一側性難聴児も 1 例確認のた めに来園した。一側性難聴は言語発達には大きな影響
はないとはいいながらも, 良聴耳の聴力変動あるいは 低下例も報告されているため, やはり保護者への注意 喚起は必要と考えられる9). したがって当園ではスク リーニング後来園した一側性難聴児に対しては 6 力月 から 1 歳の間に COR で良聴耳を周波数ごとに確認 し, 必要に応じて経過観察を実施しながら, 3 歳すぎで レシーバ検査が可能になった時点で片耳ごとの聴覚評 価を行い, 最終的にはマスキングをして非良聴耳の聴 覚閾值を測定するというスケジュールで定期的に観察 を行っている.

米国の Joint Committee on Infant Hearing が 2000 年に発行したYear 2000 Position Statement に よると生後 1 カ月以内に新生児聴覚スクリーニングを 実施し，3 月月までに聴覚および医学的評価が進めら れ，6力月までには療育が開始できるよう勧告してい る ${ }^{10)}$. 今回, 生後 3 力月までに $83.3 \%$ が難聴の診断を 受け，6力月までには $89.6 \%$ が療育の開始にいたって いた．重複障害あるいは軽度難聴が存在する症例では やはり診断ならびに療育には慎重さが求められるた め, 今後も時間を要することは否定できずその間のカ ウンセリングなどで保護者への十分なケアーが重要で ある11-14)。

リスク要因によるスクリーニングでは難聴児の約 $50 \%$ は見逃されているとされている ${ }^{15)}$. 今回ローリス ク児が有意に多かった。したがって，ローリスク児の 発見にとって新生児聴覚スクリーニングは有効であっ たといってよい. ハイリスク要因としては Fortnum の報告と同じく家族性の要因が高かった．スクリーニ ングでは正常であったため経過観察の対象とはなって いなかった家族性難聴のリスクをもつ 2 症例が, 聴覚 の確認のために来園した。したがって，家族性のリス クをもつ場合は, 必要に応じて聴覚の確認をするよう な指導が望ましいであろう。

今回, 先天性風疹症候群 4 例の発生が見られたが, 全国的に発生例の報告が少ない現状からすれば，今後 の課題の一つであろう.

Joint Committee の勧告では進行性, 遅発性のリス ク因子として 10 項目が挙げられている ${ }^{10)}$. 本スクリー ニングでも両側および一側の 1 例ずつの進行性が疑わ 
れる症例が発見された。特に両側難聴をきたす症例に ついては発見時期が療育効果に影響を及ぼすため十分 な注意が必要である。

スクリーニングはその性格上，事後の対応も十分整 えておかなければならない。実際，スクリーング時 pass で経過観察の対象外になった後, 聴こえの確認や ことばの遅れの相談を目的として来園したケースが 26 例と少なからず見られた。岡山県では Natus Algo によるスクリーニングを実施しているが，聴覚の確認 はあくまでも 700-1500 Hz を中とした周波数によ る検査であるため, 日常での観察上, 子どもの聴覚に 不安があれば相談という行動に結びつくことも当然考 えられる. 同時に聴覚スクリーニングは聴覚の障害に ついての確認にのみ限定されており, 言語発達のスク リーニングではないことは明らかである。ことばの遅 れが心配された場合必ず聴覚の障害についての確認が 必要となる.したがって, スクリーニング passであっ ても聴覚の障害についての確認が必要なケースでは音 場検査による周波数ごとの検査は今後とも重要と考元 られる。

以上，スクリーニングによって難聴が発見され早期 に療育を開始できる難聴児が急増したが, その一方で スクリーニング受診機会がなく, 1 歳前後で発見され た児の保護者が, 発見時期が遅かったと後悔した例を 経験すると，そうした意見は無視できず今後の検討課 題である.

発見が遅れる症例を少しでも減少させるため岡山県 では里㷌り出産児へのスクリーニングを提供するため のチラシの作成および外来スクリーニング機関の設置 が一つの試みとして実施されており今後の経過が注目 される. 同時に, 従来の保健所の活動や病院を通して なされてきた難聴児の早期発見システムの重要性も指 摘しておかなければならない。

\section{ま と め}

岡山県の新生児聴覚検査事業について報告した。両 側難聴は 48 例で難聴の出現率は約 $0.1 \%$ であった。聴 覚スクリーニングは新生児の軽・中等度難聴の発見に 有効で, ローリスク児の難聴発見でもその必要性が確 認された。

スクリーニング未受診児への対応は今後の課題であ る、スクリーニング後の難聴発見, あるいは聴こえや ことばの相談が少なくないことから療育的な援助の遅
れをできるだけ少なくするためには従来の早期発見の 体制がさらに重要である.

本論文の要旨は第 51 回日本音声言語医学会総会・学術講演会 (2005 年 10 月, 横浜)にて口演した.

\section{文献}

1) Hayes $D$ and Northern J: Infants and Hearing, Singular Publishing Group, San Diego • London, 1996.

2) Northern JL and Downs MP: Hearing in Children, 5th ed, Williams \& Wilkins, Baltimore, pp 23-24, 2002.

3) Marsh RR : 新生児聴覚スクリーニングへの挑戦。 小児耳, $23: 1-8,2002$.

4）加我君孝：スクリーニングの目的扔よび歷史. 新生児聴覚 スクリーニング, 金原出版, 東京, 1-3 頁, 2005.

5) Yoshinaga-Itano $\mathrm{C}$, et al: Language of early- and lateidentified children with hearing loss. Pediatrics, 102: 1161-1171, 1998.

6) 岡山県：岡山県新生児聴覚検査事業の手引き(改訂版), 2004.

7) Fortnum HM: Epidemiology of permanent childhood hearing impairment: Implications for neonatal hearing screening. Audiological Medicine, 1: 155-164, 2003.

8）福田章一郎, 湯浅健一, 井口郁雄, 他: 当園開設以来 20 年 間の難聴児発見の推移と今後の課題. Audiology Japan, $33: 695-696,1990$.

9）南 詔子：小児感音難聴の進行性一特に一側聾の反対側聴 カについて一. Audiology Japan, 43: 148-156, 2000.

10) Joint Committee on Infant Hearing: Year 2000 Position Statement: Principles and Guidelines for Early Detection and Intervention Programs. Pediatrics, 106: 798-817, 2000.

11) Luterman D: Counseling Parents of Hearing-Impaired Children, Little, Brown and Company, Boston, pp 1-22, 1979.

12）福田章一郎，塚村恵子：新生児聴覚スクリーニングで発見 された難聴児の保護者への初期介入の検討. 日本音声言語 医学会予稿集, 65 頁, 2002.

13）森田訓子, 伊藤茂彦, 山口 暁: 新生児聴覚スクリーニン グの問題点と今後の課題一保護者へのアンケート調查によ る検討一. Audiology Japan, 47 : 49-55, 2004.

14）言語聴覚士のための新生児聴覚検査と早期リハビリテーシ ヨンの手引き, 日本言語聴覚士協会, 小児聴覚小委員会, 2004.

15) NIH Concensus Statement: Early Identification of Hearing Impairment in Infants and Young Children, 1993.

別刷請求先： $=700-0927$ 岡山県岡山市西古松 321-102 岡山かなりや学園 福田章一郎 